\title{
Vascular dysfunction as a target for adjuvant therapy in cerebral malaria
}

\author{
Leonardo José de Moura Carvalho ${ }^{1,2} /{ }^{+}$, Aline da Silva Moreira1, \\ Cláudio Tadeu Daniel-Ribeiro', Yuri Chaves Martins ${ }^{3}$
}

\author{
'Laboratório de Pesquisas em Malária, Instituto Oswaldo Cruz-Fiocruz, Rio de Janeiro, RJ, Brasil \\ ${ }^{2}$ La Jolla Bioengineering Institute, San Diego, CA, USA ${ }^{3}$ Department of Pathology, Albert Einstein College of Medicine, Bronx, NY, USA
}

Cerebral malaria (CM) is a life-threatening complication of Plasmodium falciparum malaria that continues to be a major global health problem. Brain vascular dysfunction is a main factor underlying the pathogenesis of CM and can be a target for the development of adjuvant therapies for the disease. Vascular occlusion by parasitised red blood cells and vasoconstriction/vascular dysfunction results in impaired cerebral blood flow, ischaemia, hypoxia, acidosis and death. In this review, we discuss the mechanisms of vascular dysfunction in CM and the roles of low nitric oxide bioavailability, high levels of endothelin-1 and dysfunction of the angiopoietin-Tie2 axis. We also discuss the usefulness and relevance of the murine experimental model of CM by Plasmodium berghei ANKA to identify mechanisms of disease and to screen potential therapeutic interventions.

Key words: cerebral malaria - vascular dysfunction - nitric oxide

Cerebral malaria $(\mathrm{CM})$ is one of the most lethal complications of Plasmodium falciparum malaria, responsible for a large fraction of the $1,238,000$ (95\% confidence interval: 929,000-1,685,000) malaria-related deaths estimated for 2010 in 105 countries (Murray et al. 2012). The World Health Organization (WHO) defines CM as coma (incapacity to localise a painful stimulus or Blantyre coma score $\leq 2$ ) persisting at least $1 \mathrm{~h}$ after termination of a seizure or correction for hypoglycaemia in the presence of asexual $P$. falciparum parasitaemia and without the presence of other causes of encephalopathy (WHO/ CDC 2000, Trampuz et al. 2003). However, for practical purposes, any patient presenting with impaired consciousness and falciparum parasitaemia must be started on parenteral antimalarial drugs and transferred to an intensive care unit. Severe malarial anaemia, respiratory distress and hypoglycaemia are the most common concomitant complications in paediatric CM cases (Murphy \& Breman 2001), whereas jaundice, acute renal failure and hypoglycaemia are the most frequent concurrent complications occurring in adult $\mathrm{CM}$ cases (Mohanty et al. 2003, Idro et al. 2005). Up to $75 \%$ of CM-related deaths occur within $24 \mathrm{~h}$ of admission which makes the initiation of antimalarial treatment right after confirma-

doi: 10.1590/0074-0276140061

Financial support: LJMC is recipient of NIH (R01-AI082610) and FAPERJ (E-26/111.304/2011) grants and a research fellowship from CNPq (Produtividade). ASM is recipient of CAPES fellowship. CTDR is recipient of Research Fellowships from CNPq (Produtividade) and from FAPERJ (Cientista do Nosso Estado). YCM is supported by the Inter-hemispheric Research/NIH GID (D43 TW007129).

+ Corresponding author: leojmc@ioc.fiocruz.br

Received 19 February 2014

Accepted 2 April 2014 tion of malarial parasitaemia a priority over further diagnostic work up (Idro et al. 2005). Recent studies showed that intravenous artesunate is superior to intramuscular artemether or intravenous quinine and it is currently recommended as the treatment of choice for CM $(2.4 \mathrm{mg} / \mathrm{kg}$ bolus on admission, at $12 \mathrm{~h}$ and $24 \mathrm{~h}$, thereafter once daily until oral medication can be taken reliably) (Dondorp et al. 2005, 2010). Despite the efficacy of intravenous artesunate, mortality by severe malaria in general, and by $\mathrm{CM}$ in particular, is still high even when clinical trials provide adequate patient care, as observed in the South East Asian Quinine Artesunate Malaria Trial (adults) and Africa Quinine Artesunate Malaria Trial (children) (Dondorp et al. 2005, 2010). In addition, 11\% of children surviving $\mathrm{CM}$ present gross neurological deficits at discharge (most commonly spasticity, ataxia, hemiplegia, speech disorders and blindness) and up to $25 \%$ may sustain long-term cognitive deficits (Brewster et al. 1990, Boivin 2002, Carter et al. 2005, Boivin et al. 2007, John et al. 2008). Development of adjuvant therapies is therefore urgently necessary to modify the high rates of mortality and sequelae resulting from CM.

CM pathogenesis: a central role for vascular dysfunction - The pathogenesis of CM is still poorly understood. The histopathological hallmark of $\mathrm{CM}$ is the sequestration of parasitised red blood cells (pRBCs) in the brain of patients that died of CM (Pongponratn et al. 1991, 2003). Quantitative analysis of brain sections in necropsy studies of patients in Thailand and Vietnam showed that CM patients had more sequestered pRBCs in the brain than patients that died of other malaria complications. In addition, pRBC accumulation in the brain of CM patients was also higher than in other vital organs (Pongponratn et al. 1991, 2003). P. falciparum pRBCs adhere to endothelial cells through ligand-receptor interactions mediated by a family of variant antigens expressed by the parasites and exported to the surface 
of the RBC. The P. falciparum erythrocyte membrane protein-1 (PfEMP1) is encoded by approximately 60 vargenes in the $P$. falciparum genome, but usually only one variant is expressed at a time by each individual parasite (Kraemer \& Smith 2006, Scherf et al. 2008). These proteins have characteristic motifs that signal for their export to the $\mathrm{RBC}$ membrane, where they accumulate in protuberant structures known as knobs. Different PfEMP1 variants can interact with different receptors in endothelial cells. Several ligands have been identified, among them CD36 (Barnwell et al. 1989), ICAM1 (Berendt et al. 1989, Brown et al. 2013), thrombospondin (Roberts et al. 1985) and chondroitin sulphate (Reeder et al. 1999). A potential role for ICAM1 in pRBC sequestration in the inflamed endothelium of brain vessels has been described (Turner et al. 1994, Silamut et al. 1999) and patients that died of CM showed high expression of ICAM1 in the brain (Silamut et al. 1999). Inflammation indeed has been linked to sequestration and coagulation as critical factors for CM development (van der Heyde et al. 2006, Moxon et al. 2013) and recent work has shown that markers of inflammation and endothelial activation such as plasma levels of soluble ICAM1, C-reactive protein and angiopoietin-2 are elevated at hospital admission of children with $\mathrm{CM}$ and remain high even after successful treatment with antimalarial drugs (Moxon et al. 2014). More recently, it was demonstrated that severe malaria and CM are associated with the expression of specific PfEMP1 subtypes containing domain cassette 8 (Lavstsen et al. 2012, Bertin et al. 2013), whose binding to endothelial cells is mediated by endothelial protein $\mathrm{C}$ receptor, a host receptor involved in anticoagulation and endothelial cytoprotection and quiescence (Turner et al. 2013).

Adherence of large numbers of $\mathrm{pRBC}$ to the endothelium of brain post-capillary venules would plug the vessels, leading to mechanical occlusion, impaired blood flow with resulting ischaemia and tissue hypoxia (Marsh et al. 1996). In fact, microvascular congestion and $\mathrm{pRBC}$ sequestration were independent predictors of clinical diagnosis of CM (Ponsford et al. 2012). In addition, retinal angiography studies in children with CM showed the frequent occurrence of impaired perfusion, vessel occlusion and filling defects likely due to $\mathrm{pRBC}$ sequestration in the retinal microvasculature (Beare et al. 2009). Single photon emission computed tomography also indicated the occurrence of marked cerebral hypoperfusion in a CM patient (Kampfl et al. 1997, Beare et al. 2006). These findings evidence hypoxia and ischaemia as important components in the pathogenesis of CM. Mechanical obstruction of blood flow by adherent pRBCs has long been considered as the central mechanism leading to CM (Aikawa et al. 1987, Pongponratn et al. 2003, White et al. 2010, 2013). However, it is becoming increasingly clear that blood vessel function in CM is compromised well beyond occlusion. Spastic constriction of cerebral arterioles has been identified in CM patients (Polder et al. 1991). In addition, severe malaria patients show lower reactive hyperaemia-peripheral arterial tonometry (RHPAT) index (a measurement of reactive vasodilation) than uninfected controls or patients with uncomplicated malaria (Yeo et al. 2007). The mechanisms behind va- soconstriction and vascular dysfunction in $\mathrm{CM}$ are not completely understood, although mediators such as nitric oxide (NO), endothelins and the angiopoietin-Tie2 axis seem to be involved (Wenisch et al. 1996, Yeo et al. 2007, 2008a, Dietmann et al. 2008, Conroy et al. 2009, Lovegrove et al. 2009, Jain et al. 2011).

NO in human CM - NO is a small gaseous molecule with a central role in the maintenance and regulation of vascular tone (Ignarro et al. 1987). NO is generated from the amino acid (aa) L-arginine (L-Arg) by three isoforms of the enzyme NO synthase (NOS). Two of the isoforms are expressed constitutively in endothelial cells [endothelial NOS (eNOS)] or in neurons [neuronal NOS (nNOS)], whereas inducible NOS (iNOS) is expressed in several cell types, mainly phagocytes, upon stimuli such as a proinflammatory cytokines (Forstermann \& Sessa 2012). eNOS is the main isoform regulating vascular tonus systemically, $\mathrm{nNOS}$ being also important in the regulation of cerebral blood flow. NO overproduction by iNOS during pathological conditions such as sepsis may cause lifethreatening hypotension (Boisramé-Helms et al. 2013). In physiological conditions, NO produced by eNOS in endothelial cells diffuses to the neighbouring vascular smooth muscle cells where it activates soluble guanylate cyclase (sGC) that, in turn, generates cyclic guanosine monophosphate (cGMP). cGMP activates protein kinase $\mathrm{G}$, which causes reuptake of $\mathrm{Ca}++$ and the opening of calcium-activated potassium channels. The fall in concentration of $\mathrm{Ca}++$ ensures that the myosin light-chain kinase can no longer phosphorylate the myosin molecule, thereby leading to relaxation of the smooth muscle cell, causing vasodilation and increasing blood flow.

Low NO bioavailability has been described in several haemolytic disorders (Rother et al. 2005, Morris et al. 2008). Haemolysis causes gram quantities of haemoglobin to be released in the bloodstream. Cellfree plasma haemoglobin is a potent scavenger of NO and will deplete most of the NO that is produced by endothelial cells (Rother et al. 2005). More recently, it has been shown that RBC microparticles formed during pathological haemolysis also scavenge $\mathrm{NO}$ with similar potency to cell-free haemoglobin (Liu et al. 2013). In addition, $\mathrm{RBC}$ arginase is released in the plasma during haemolysis and will compete with NOS for the same substrate, L-Arg, depleting it (Rother et al. 2005). Finally, L-Arg transport across RBC membrane is impaired and arginase-mediated L-Arg consumption enhanced by free plasma haeme released from cell-free haemoglobin (Omodeo-Salè et al. 2010). Impaired NO bioavailability represents the central feature of endothelial dysfunction observed in haemolytic disorders (Morris et al. 2008). The consequences of impaired NO bioavailability include vasoconstriction, reduced blood flow, impaired reactivity of blood vessels to dilation stimuli, acquisition of a pro-inflammatory, pro-adhesive phenotype by endothelial cells, loss of endothelial cell-cell junctional cohesiveness, among other alterations.

A seminal study in Tanzania showed that plasma and urine levels of nitrite and nitrate (stable metabolites of NO) were inversely correlated with malaria severity in children (Anstey et al. 1996). This finding was con- 
firmed later in patients with $\mathrm{CM}$ who showed decreased plasma and cerebrospinal levels of nitrite and nitrate (Dondorp et al. 1998). In vitro, inhibition of NO production by treatment of human microvascular endothelial cell with the NOS inhibitor L-N(G)-nitro-argininemethyl-ester (L-NAME) enhanced P. falciparum pRBC adhesion, whereas addition of a NO-donor reduced adhesion (Serirom et al. 2003). Patients with CM showed low levels of L-Arg, the substrate for NO generation by NOS isoforms and hypoargininaemia was significantly associated with CM case-fatality (Lopansri et al. 2003). Severe malaria patients showed endothelial dysfunction characterised by lower levels of exhaled NO and lower reactive RH-PAT index than uninfected controls or patients with moderately severe malaria (Yeo et al. 2007). Endothelial dysfunction was also associated with elevated blood lactate and measures of haemolysis. Recovery of endothelial function in severe malaria was shown to be associated with recovery from hypoargininaemia and lactic acidosis and the median time to normal endothelial function was $49 \mathrm{~h}$ after the start of antimalarial therapy (Yeo et al. 2008b). Cell-free haemoglobin concentrations in patients with severe malaria were significantly higher than in those with moderately severe malaria or controls and were independently associated with lactate, endothelial activation and proinflammatory cytokinaemia (Yeo et al. 2009). In addition, plasma levels of asymmetrical dimethylarginine (ADMA), an endogenous inhibitor of NOS, were shown to be elevated in adults with severe malaria. ADMA levels were associated with decreased exhaled NO and endothelial function and shown to be an independent predictor of mortality (Yeo et al. 2010a). In children with severe malaria, although ADMA levels were actually low, the L-Arg to ADMA ratio was even lower due to severe hypoargininaemia (Weinberg et al. 2014). Intravenous infusion of L-Arg increased the RHPAT index and exhaled NO levels in patients with moderately severe malaria (Yeo et al. 2007) was shown to be safe (Yeo et al. 2008a) and to result in sustained plasma levels of L-Arg (Yeo et al. 2008d). However, in a recent randomised pilot study of intravenous L-Arg infusion in Indonesian adults with severe malaria, no effect on lactate clearance or endothelial NO bioavailability (RHPAT index) was observed (Yeo et al. 2013). A clinical trial with inhaled $\mathrm{NO}$ in Ugandan children with $\mathrm{CM}$ is ongoing (Hawkes et al. 2011).

Endothelins in human CM - Endothelins are potent regulators of the vascular tone that also have mitogenic, apoptotic and immunomodulatory properties (Rubanyi \& Polokoff 1994, Kedzierski \& Yanagisawa 2001, Bagnato et al. 2011). These characteristics make endothelins important regulators of pulmonary and systemic arterial pressure, kidney function, angiogenesis, inflammation and adaptive immune function (Bagnato et al. 2011, Guo et al. 2012, Kohan et al. 2012). Three isoforms of endothelin have been identified (ET-1, ET-2 and ET-3), all are 21 aa peptides produced by the same metabolic pathways and act through the same receptors (Masaki 2004). However, each isoform is encoded by a different gene and has a different tissue expression (Saida et al.
2002). ET-1 is the best studied, the most abundant and is synthesised by vascular endothelial cells throughout the body as well as by a variety of other cells, including leukocytes, fibroblasts, vascular smooth muscle cells, neurons and astrocytes (Vignon-Zellweger et al. 2012). Endothelin precursors are called big-endothelins (bigET-1, big-ET-2 and big-ET-3) which bind to the endothelin receptors with a much lower affinity (Hemsén et al. 1991). All three isoforms of endothelin are synthesised by the cleavage of their precursors by one of the three endothelin converting enzymes (ECE-1, ECE-2 and ECE-3). Once synthesised, endothelins can act through two transmembrane $\mathrm{G}$ protein-coupled receptors called endothelin receptor A (ETA) (Arai et al. 1990) and B (ETB) (Sakurai et al. 1990). ETA and ETB receptors can have synergetic or opposing effects depending on cell type, tissue type or physiological situation (Vignon-Zellweger et al. 2012). In addition, the distribution of ETA and ETB receptors varies in each vascular bed and they also can form homo and heterodimers, which increases the complexity of possible responses to endothelins (Caló et al. 1996, Evans \& Walker 2008, Vignon-Zellweger et al. 2012). For example, ET-1 is classically considered a potent vasoconstrictor acting by increasing intracellular $\mathrm{Ca} 2+$ on vascular smooth muscle cells via ETA receptor binding (Wagner et al. 1992). However, ET-1 can also cause vasodilation by acting via ETB receptors on endothelial cells, which promotes NO release (Tsukahara et al. 1994). Hence, the actual knowledge suggests that the effects of endothelins may differ depending on the physiological or pathological situations (Bagnato et al. 2011, Vignon-Zellweger et al. 2012).

ET-1 has been implicated in the pathogenesis of a number of infectious, cardiovascular, cerebrovascular, renal, oncologic, chronic degenerative, inflammatory and auto-immune diseases (Edvinsson 2009, Bagnato et al. 2011, Guo et al. 2012, Kohan et al. 2012). Only two human studies analysing ET-1 during malaria infection are available to date (Wenisch et al. 1996, Dietmann et al. 2008). They showed that ET-1 and big-ET-1 were increased in the serum of patients with complicated $P$. falciparum malaria when compared with healthy controls. However, except for serum tumour necrosis factor-alpha levels and thrombocytopenia, these studies did not find a correlation between the serum levels of ET-1 or big-ET-1 and disease severity. In vitro studies showed that parasite derived lipid moieties present in the membrane of $P$. falciparum-infected RBCs and haemozoin (malaria pigment) can bind ET-1 (Basilico et al. 2010). The authors speculate that this unspecific binding could neutralise ET-1 activity by decreasing its bioavailability in the local microenvironment where $\mathrm{pRBC}$ sequester. However, the opposite could also be true. pRBC could be a source of ET-1, actually increasing its concentrations and bioavailability in sites of parasite sequestration contributing to the pathogenesis of falciparum complications such as $\mathrm{CM}$. This could also explain the apparent decrease in serum ET-1 levels in patients with severe malaria when compared to uncomplicated malaria patients. These findings indicate that endothelins are involved in CM vascular dysfunction. However, the role of ET-1, ET-2 and ET-3 during human 
CM needs to be further analysed. ET-3 is of particular interest as it is produced in the brain by endothelial cells and astrocytes and has been shown to cause brain ischaemia and inflammation (Ehrenreich et al. 1991, Filipovich \& Fleisher-Berkovich 2008, Li et al. 2010).

Angiopoietin-Tie2 axis in human CM - AngiopoietinTie-2 axis dysfunction is involved in the pathogenesis of several vascular, infectious and oncologic diseases such as breast and lung cancer, hepatocellular carcinoma, atherosclerosis, pre-eclampsia, pulmonary hypertension, thrombosis, vasculitis and infections (Ahmed \& Fujisawa 2011, Carrol 2011, David et al. 2013, Diaz-Sanchez et al. 2013, Fagiani \& Christofori 2013). Angiopoietins (Ang) are $~ 70$ $\mathrm{kDa}$ glycoproteins that critically regulate endothelial reactivity to angiogenic and inflammatory factors (Fiedler \& Augustin 2006, Fagiani \& Christofori 2013). Four distinct Ang have been described until now: Ang-1, Ang-2, Ang-3 and Ang-4. Ang-1, 3 and 4 are agonists of the receptor Tie-2 (acronym for tyrosine kinase with immunoglobulin and endothelial growth factor homology domains) (Davis et al. 1996, Fagiani \& Christofori 2013). Ang-2 is a partial/ weak agonist of Tie-2 that physiologically acts as a context antagonist of Ang-1 (Maisonpierre et al. 1997, Yuan et al. 2009). Tie-2 receptors are expressed mainly by endothelial cells, but they are also present in neurons, astroglial cells, pericytes and smooth muscle cells (Prapansilp et al. 2013). Ang-1 is incorporated in the extracellular matrix after its release by perivascular cells such as pericytes, vascular smooth muscle cells, platelets and fibroblasts (Davis et al. 1996, Xu \& Yu 2001, Milner et al. 2009, Fagiani \& Christofori 2013). Ang-1 mediated activation of Tie-2 receptors present on endothelial cells induces endothelial quiescence by inhibiting apoptosis, promoting NO synthesis, increasing the expression of endothelial cell tight junctions and reducing the expression of adhesion molecules such as ICAM-1, VCAM-1 and E-selectin (Jones et al. 1999, 2003, Kim et al. 2001, Saharinen et al. 2008). Therefore, although not formally proven, it is widely believed that continuous Tie-2 activation by Ang-1 maintains vascular quiescence during healthy states (Fiedler \& Augustin 2006, Fagiani \& Christofori 2013). Ang-2 is synthesised by endothelial cells and stored inside their specialised granules, Weibel-Palade bodies, for rapid release upon stimulation by angiogenic or inflammatory mediators (Fiedler et al. 2004). As Ang-2 is a weaker partial agonist of Tie-2, in the presence of Ang-1, Ang-2 act mainly as a competitive antagonist inhibiting Tie-2 signalling by displacing Ang-1 from the receptor (Yuan et al. 2009). Hence, release of Ang-2 destabilises the endothelium via an autocrine mechanism increasing its reactivity to angiogenic and inflammatory stimuli, promoting vascular permeability and up-regulating ICAM-1 and VCAM-1 (Maisonpierre et al. 1997, Hammes et al. 2004, Fiedler et al. 2006). Taken together, these data indicate that the Ang-2/Ang-1 ratio determines the functional status of the vasculature (Fiedler \& Augustin 2006). Physiologically, a low Ang-2/Ang-1 ratio controls vascular responsiveness and keeps endothelium homeostasis. However, following local or systemic endothelial-cell activation, Ang-2 is rapidly released from Weibel-Palade bodies increasing the Ang-2/Ang-1 ratio and the endothelial responsiveness. Ang-3 and Ang-4 are much less studied being orthologous proteins found in mouse and human, respectively (Fagiani \& Christofori 2013). Both Ang-3 and Ang-4 are able to induce angiogenesis in vivo, but their role during inflammation is not understood (Lee et al. 2004).

It is well known that endothelial activation is associated with CM development (Grau \& Craig 2012). As Ang are key regulators of endothelial responsiveness, deregulated levels of Ang-1 and Ang-2 systemically or locally in the brain could be involved in the pathogenesis of CM and other falciparum complications. Several human studies showed that decreased Ang-1 and increased Ang-2 levels and elevated Ang-2/Ang-1 ratio are associated with development of severe malaria (Yeo et al. 2008c, Conroy et al. 2009, 2010, 2012, Silver et al. 2010, Erdman et al. 2011, Lucchi et al. 2011, Prapansilp et al. 2013). These alterations in serum Ang-1 and Ang-2 correlate with disease severity, mortality and seem to be particularly more prominent in patients with $\mathrm{CM}$ than with other complications of malaria (Conroy et al. 2009, Lovegrove et al. 2009, Jain et al. 2011). In addition, serum levels of Ang-2 and the soluble version of Tie- 2 receptor are associated with CM retinopathy in children (Conroy et al. 2010, 2012). Increased Ang-2 levels and Ang-2/Ang-1 ratio were shown to be better predictors of disease severity and mortality than Ang-1 in CM, indicating that the increase in endothelium responsiveness during $\mathrm{CM}$ may be due to increased Ang-2 rather than decreased Ang-1 levels (Conroy et al. 2009, 2010, 2012). Plasma levels of Ang-2, as well as of soluble ICAM1 and C-reactive protein, remain elevated, even days or weeks after antimalarial treatment, in children admitted with $\mathrm{CM}$, indicating persistent inflammation and endothelial activation (Moxon et al. 2014).

Deregulation of the angiopoietin-Tie-2 axis, however, is not specific of CM. Increased serum Ang-2 levels are also present during Plasmodium vivax infection, a parasite species that classically does not cause severe disease (Yeo et al. 2010b, MacMullin et al. 2012). In addition, a recent study with Vietnamese adults failed to show differences in the brain expression of Ang-1, Ang-2 and Tie-2 on endothelial cells, astroglial cells or neurons between $\mathrm{CM}$ and non-CM controls presenting confirmed multi-organ dysfunction (Prapansilp et al. 2013). Although Ang-1 and Ang-2 expression in neurons was correlated with the incidence of haemorrhages, there was no correlation between the expression of Ang-1, Ang-2 and Tie-2 and $\mathrm{pRBC}$ sequestration in the brain. The authors conclude that although angiopoietin-Tie-2 axis dysfunction is related to severity and outcome, it is not a specific event in the brain during $\mathrm{CM}$. These data suggest that disruption of endothelial quiescence seems to be necessary, but not sufficient to cause CM. Several approaches have been used to modulate the systemic levels of Ang-1, Ang-2 and the Ang-2/Ang-1 ratio in murine models of sepsis with some of them showing promising results such as the use of vasculotide, a synthetic agonist of Tie-2 (Fiedler \& Augustin 2006). These approaches could be used in the murine model of CM to reveal the importance of each mediator during the course of the disease and potential adjunctive therapies for $\mathrm{CM}$ and severe malaria. 
Experimental models of CM: a way forward to identify mechanisms of vascular dysfunction and evaluate therapeutic interventions - Studies of CM pathogenesis and therapeutics in humans are subjected to several constraints. Most studies on CM rely on post-mortem brain samples, which provide important clues for the understanding of its pathogenesis. Nevertheless, while this material provides evidence of the damage inflicted in fatal cases, it may be deficient in teaching its processes and mechanisms and cannot be compared with patients with more favourable outcomes (Looareesuwan et al. 2009). In addition, in most cases these samples are obtained from patients that received antimalarial treatment for hours or days and it is hard to measure how the intervention affected the observed alterations. Ocular fundus examination allows for the determination some aspects of pathology in live patients being particularly useful for improving the specificity of CM diagnosis (Lewallen et al. 1993, White et al. 2001). Also, it will possibly be valuable as readout for evaluation of potential novel therapeutic interventions. A few magnetic resonance studies have been performed and this is a promising approach to study CM pathogenesis in live patients, however this is an expensive resource largely unavailable in malaria endemic areas and its use may pose some ethical concerns (Looareesuwan et al. 1995, 2009, Potchen et al. 2012, Kampondeni et al. 2013).

There is no animal model that can perfectly mimic human CM. Non-human primate models of CM have been described, for instance a CM-like syndrome occurs in Macaca mulatta monkeys infected with Plasmodium coatneyi (de Souza \& Riley 2002). However, this and other primate models are largely unavailable for systematic studies and therefore lack extensive characterisation. The best studied animal model for CM is the infection of susceptible mouse strains by the rodent parasite Plasmodium berghei ANKA, which induces a fatal neurological syndrome known as experimental CM (ECM) with clinical signs such as ataxia, convulsions, limb paralysis and coma (de Souza et al. 2010). The brain of mice with ECM show vascular plugging mainly by adherent leukocytes, diffuse microhaemorrhages, breakdown of the blood brain barrier (BBB) and increased expression of cell adhesion molecules such as ICAM1 (Martins et al. 2009, Cabrales et al. 2011, Zanini et al. 2011). The relevance of this animal model for the human disease has been heatedly debated recently (Carvalho 2010, Hunt et al. 2010, Rénia et al. 2010, Riley et al. 2010, Stevenson et al. 2010, White et al. 2010, Langhorne et al. 2011, Craig et al. 2012). The main criticism lies on the fact that in human $\mathrm{CM}$ the key histological finding is the occlusion of brain post-capillary venules by P. falciparum $\mathrm{pRBC}$, whereas in ECM post-capillary venular occlusion is mediated mostly by adherent activated leukocytes. However, leukocytes are found in the brain of CM patients (Pongponratn et al. 2003) and pRBC accumulate in the brain of mice with ECM (Amante et al. 2010, Baptista et al. 2010, Franke-Fayard et al. 2010, Riley et al. 2010), although the $\mathrm{pRBC} /$ leukocyte proportion is different, being higher in human CM. Markers of brain inflammation such as high levels of ICAM-1 expression in the endothelium is observed in both conditions and neces- sary for sequestration. It has been claimed that adjunctive therapies in ECM are highly effective, contrary to what has been observed in human CM, but in the murine studies the therapies cited as "adjunctive" do not fit this definition (Carvalho 2010). Finally, a large amount of evidence showing several similarities between human and murine $\mathrm{CM}$ has not been considered (van der Heyde et al. 2006, de Souza et al. 2010, Hunt et al. 2010).

The murine CM model has been instrumental in studying the role of vascular dysfunction in the pathogenesis of CM. Several aspects of vascular pathology have been shown to mimic very closely the findings in the human disease. Contrary to initial hypotheses (Clark et al. 1991), studies in this model showed that NO deficiency rather than excess NO production was involved in ECM pathogenesis. Administration of NOS inhibitors such as L-N-monomethyl arginine and $\mathrm{N}$ omega-nitroL-Arg or aminoguanidine L-NAME, even intracranially, did not modify disease outcome (Asensio et al. 1993, Kremsner et al. 1993, Favre et al. 1999). Mice deficient in either eNOS or iNOS were as susceptible to ECM as wild-type mice and wild-type mice with ECM were shown to display low NO bioavailability, with decreased levels of plasma and brain nitrite/nitrate (stable products of NO), decreased levels of L-Arg (the substrate for NO synthesis by NOS) and decreased brain cGMP levels (the downstream product of NO-stimulated soluble sGC) (Gramaglia et al. 2006). Mice with ECM also showed high levels of plasma cell-free haemoglobin, which was shown to scavenge $\mathrm{NO}$ and therefore being a major responsible for NO deficiency. Finally, administration of exogenous NO by means of the NO-donor molecule DPTA-NO or by inhaled NO gas to P. berghei-infected mice was shown to prevent ECM, decreasing inflammatory and endothelial activation markers and preventing BBB breakdown (Gramaglia et al. 2006, Serghides et al. 2011).

In ECM, mRNA expression of ET-1, ECE, ETA and ETB are markedly increased during infection (Machado et al. 2006, Lovegrove et al. 2007). In addition, the pharmacologic blockade of ETA receptors decreased the incidence of haemorrhages in the brain and seemed to increase survival when used in conjunction with artemether to treat mice with CM (Dai et al. 2012). High ET-1 levels could be responsible for the intense vasoconstriction and ischaemia that occur in the brain of mice with ECM (Kennan et al. 2005, Machado et al. 2006, Cabrales et al. 2010). Elevated concentrations of ET-1 also can lead to decreased NO production (Ramzy et al. 2006), increased synthesis of pro-inflammatory mediators by monocytes (Simonson 1993, Browatzki et al. 2005), increased expression of leukocyte adhesion molecules by brain endothelial cells (McCarron et al. 1993), dysfunction of the platelet anti-aggregating properties of neutrophils (Gómez-Garre et al. 1992) and disruption of the integrity of the BBB (Matsuo et al. 2001, Reijerkerk et al. 2012), alterations that are present in the brain of mice with $\mathrm{CM}$ (Gay et al. 2012, Grau \& Craig 2012, Rénia et al. 2012).

Few studies have explored the role of Ang in ECM. Improved survival in ECM was associated with decreased endothelial activation (increased Ang-1, decreased Ang-2 and soluble ICAM-1) upon preventative 
treatment of PbA-infected mice with inhaled $\mathrm{NO}$, neuregulin-1 or with compounds that modulate the levels of sphingosine 1-phosphate or in mice deficient for the C5a receptor (Finney et al. 2011, Serghides et al. 2011, Kim et al. 2014, Solomon et al. 2014). Furthermore, PbA-infected mice treated early during infection with artesunate in combination with either inhaled NO or the peroxisome proliferator-activated receptor $\gamma$ agonist rosiglitazone showed improved survival and cognitive function than mice treated with artesunate plus saline (Serghides et al. 2011, 2014). Treatment with rosiglitazone resulted in increased plasma levels and brain expression of Ang-1.

We developed an intravital microscopy methodology for studying in detail the features of cerebral vascular dysfunction and $\mathrm{NO}$ deficiency in $\mathrm{CM}$ pathogenesis and therapeutics using this mouse model (Cabrales \& Carvalho 2010). For this, a chronic closed cranial window is surgically implanted in the mouse's parietal bone allowing access to the pial microcirculation over extended periods of time. $P$. berghei ANKA-infected mice showed marked decreases in cerebral blood flow at the time of ECM manifestation, due to reduced RBC velocities and to widespread cerebral vasoconstriction, similar to the vasospasm phenomenon observed after subarachnoid haemorrhages (Cabrales et al. 2010). The decrease in blood flow associated with decreased haematocrit lead to hypoxia and acidosis, with a marked decrease in oxygen tension in brain arterioles, venules and the perivascular tissue in mice with ECM (Cabrales et al. 2013). Administration of the NO-donor DPTA-NO was able to ameliorate, but not completely prevent the microcirculatory complications of ECM (Cabrales et al. 2011, Zanini et al. 2011). DPTA-NO improved cerebral blood flow mainly by preventing vasoconstriction, with a beneficial effect more pronounced in smaller than in larger arterioles. DPTA-NO also decreased brain vascular inflammation by decreasing the expression of endothelial cell adhesion molecules such as ICAM1 and P-selectin, resulting in decreased leukocyte and platelet adherence and in decreased vascular resistance to blood flow. DPTA-NO treatment also decreased vascular leakage and the incidence of microhaemorrhages. DPTA-NO is a potent NO-donor and in the dose used (1 mg/mouse) it releases large amounts of NO in a short period of time resulting in marked hypotension in normal mice (Gramaglia et al. 2006). Therefore, it is useful as a research tool, but has limited potential as a therapeutic intervention. Inhaled NO is an alternative with therapeutic potential and shown to be effective in both preventing ECM as well as an adjunctive therapy with artesunate (Gramaglia et al. 2006, Serghides et al. 2011). S-nitrosylated glutathione (GSNO) is a physiological NO-donor and NO reservoir and might have better therapeutic potential. GSNO indeed largely prevented ECM incidence (Zanini et al. 2012). At higher dose (1 mg/ mouse), it even affected parasite growth decreasing parasitaemia and completely preventing ECM incidence. At lower doses it largely prevented ECM incidence without affecting parasitaemia. The higher dose, however, showed a hypotensive effect similar to DPTA-NO, which was not observed with the lower doses. Interestingly, mice with ECM showed marked depletion of brain glutathione lev- els, indicating increased oxidative stress, but GSNO administration had little or no effect on restoring proper glutathione levels. Other attempted approaches to increase NO bioavailability such as L-Arg and tetrahydrobiopterin (BH4) supplementation with or without arginase inhibition or nitrite administration did not result in protection from ECM, at least in the doses and schemes used (Martins et al. 2012).The phosphodiesterase-5 inhibitor sildenafil by itself did not protect from ECM either, however in combination with a lower dose of DPTA-NO $(0.1 \mathrm{mg} /$ mouse, also shown to be ineffective in preventing ECM) was able to increase survival of $\mathrm{PbA}$-infected mice with milder effects on blood pressure than the higher dose of DPTA-NO (1 mg/mouse).

Interventions given early during infection, as the approaches described above, are informative about mechanisms of disease and provide evidence on the role of NO and vascular dysfunction in the pathogenesis of the neurological syndrome. However, from these experiments it is not possible to derive information about the therapeutic potential of interventions. This information can be achieved only by testing interventions in latestage disease in combination with antimalarial drugs such as artemisinin derivatives, the mainstay treatment for $\mathrm{CM}$ in humans. A model to test adjuvant therapies for ECM was described in which mice with late-stage ECM, determined by well-defined clinical parameters such as motor scores and degree of hypothermia, were treated with different antimalarial drugs, showing that artesunate and artemether were the most effective in rescuing animals from death (Clemmer et al. 2011). This model has been used to evaluate the efficacy of adjuvant therapies. Administration of the dihydropiridine calcium channel blocker nimodipine, the drug used to prevent vasospasm in sub-arachnoid haemorrhage patients (Keyrouz \& Diringer 2007), in combination with artemether improved cerebral blood flow and increased survival of mice with late-stage ECM when compared to artemether alone (Cabrales et al. 2010). An improved nimodipine delivery system using subcutaneous miniosmotic pumps resulted in efficacy in increasing survival while avoiding deleterious effects on cardiovascular parameters such as heart rate and blood pressure (Martins et al. 2013). Similar findings were obtained with glyceryl trinitrate (GTN). GTN is an NO-donor that requires enzymatic transformation in order to release NO. GTN applied to mice with late-stage ECM in the form of transdermal patches increased survival and, despite the high doses needed for its efficacy in rescuing ECM mice, it did not further decrease blood pressure in hypotensive mice. Importantly, transdermal GTN reversed cerebrovascular constriction soon after administration and the effect lasted for the time the patch was applied $(24 \mathrm{~h})$, whereas this effect was not observed in mice receiving artemether only (Orjuela-Sánchez et al. 2013). Similarly, inhaled NO in combination with artesunate improved survival of $\mathrm{PbA}$-infected mice compared to artesunate alone (Serghides et al. 2011). These data show that reversing hypoperfusion by tackling vasoconstriction is a life-saving intervention in ECM and therefore holds potential for translation to the clinical setting. 
While directly providing exogenous NO or other vasodilators such as calcium channel blockers constitute a potentially translatable strategy to restore cerebral perfusion during $\mathrm{CM}$, a better understanding of the mechanisms of vascular dysfunction may reveal improved targets for intervention. We have developed a new cranial window procedure allowing implantation of a superfusion chamber to study cerebrovascular functionality in mice with ECM (Ong et al. 2013a). Using this system, we found that eNOS and nNOS dysfunction are at least partially responsible for the impaired cerebrovascular responses to endothelium-dependent and neuron-dependent vasodilation stimuli (Ong et al. 2013b). Contrary to normal animals, pial arterioles of mice with ECM did not respond (dilate) to acetylcholine (ACh) (which dilates arterioles via NO production by eNOS) or to N-methyl-D-aspartate (NMDA) (which dilates arterioles via NO production by nNOS). ACh and NMDA induced generation of NO (measured as nitrite/nitrate metabolites) during pial superfusion in normal animals, which was abolished by the NOS inhibitor NG-methyl-L-Arg, but no nitrite/nitrate production was observed upon ACh or NMDA superfusion in mice with ECM. Arteriolar responses were partially restored by adding $\mathrm{BH} 4$, an essential cofactor for NOS, to the superfusate, suggesting that BH4 shortage may be implicated in NOS dysfunction. C57BL/6 mice infected with $P$. berghei NK65, which does not induce ECM, showed preserved pial arteriolar responses to ACh and NMDA, indicating that eNOS and nNOS dysfunction is specific for the ECM syndrome. Another important aspect of endothelial dysfunction in ECM is related to the vessel wall shear stress. Mice with ECM show increased expression of iNOS and eNOS. However, total NOS activity is decreased and vascular reactivity to vasodilators is impaired, as described above. Although eNOS expression is increased, eNOS phosphorylation is decreased, indicating deficient stimulation of the endothelium by mechanical forces related to blood flow. Indeed, wall shear stress is decreased in ECM (Ong et al. 2013b). In addition to resulting in deficient eNOS activation, decreased shear stress favours $\mathrm{pRBC}$ and leukocyte adherence to the endothelium and prevents their washout. In patients that die of $\mathrm{CM}$, persistent adherence of pRBC containing dead parasites or $\mathrm{pRBC}$ ghosts contributes to persistent vascular occlusion and pathology (Pongponratn et al. 2003).

Cerebral hypoperfusion in CM is mainly a consequence of two factors: vascular occlusion and vasoconstriction. These two factors greatly decrease the amount of blood that flows to the brain during CM. Interestingly, although artemether rapidly decreases parasitaemia and vascular occlusion in the first $24 \mathrm{~h}$ of treatment of mice with late-stage ECM (Clemmer et al. 2011), it has no effect on arteriolar constriction (Orjuela-Sánchez et al. 2013). Being more persistent than vascular obstruction, vasoconstriction represents a fundamental obstacle to restore perfusion in ECM. Reversing constriction is therefore a key intervention to preserve life in moribund individuals. By reversing constriction, blood flow is increased and oxygen delivery is improved, reversing hypoxia and its consequences such as acidosis. With normal vascular tonus restored, resistance to blood flow decreases and normal shear stress helps washing out adhered cells.

\section{REFERENCES}

Ahmed A, Fujisawa T 2011. Multiple roles of angiopoietins in atherogenesis. Curr Opin Lipidol 22: 380-385.

Aikawa M, Than T, Aye TM, Myint PT, Igarashi I, Schoene WC 1987. Human cerebral malaria: a pathological study. J Neuropathol Exp Neurol 46: 223-231.

Amante FH, Haque A, Stanley AC, Rivera FL, Randall LM, Wilson YA, Yeo G, Pieper C, Crabb BS, de Koning-Ward TF, Lundie RJ, Good MF, Pinzon-Charry A, Pearson MS, Duke MG, McManus DP, Loukas A, Hill GR, Engwerda CR 2010. Immune-mediated mechanisms of parasite tissue sequestration during experimental cerebral malaria. J Immunol 185: 3632-3642.

Anstey NM, Weinberg JB, Hassanali MY, Mwaikambo ED, Manyenga D, Misukonis MA, Arnelle DR, Hollis D, McDonald MI, Granger DL 1996. Nitric oxide in Tanzanian children with malaria: inverse relationship between malaria severity and nitric oxide production/ nitric oxide synthase type 2 expression. J Exp Med 184: 557-567.

Arai H, Hori S, Aramori I, Ohkubo H, Nakanishi S 1990. Cloning and expression of a cDNA encoding an endothelin receptor. Nature 348: $730-732$.

Asensio VC, Oshima H, Falanga PB 1993. Plasmodium berghei: is nitric oxide involved in the pathogenesis of mouse cerebral malaria? Exp Parasitol 77: 111-117.

Bagnato A, Loizidou M, Pflug BR, Curwen J, Growcott J 2011. Role of the endothelin axis and its antagonists in the treatment of cancer. Br J Pharmacol 163: 220-233.

Baptista FG, Pamplona A, Pena AC, Mota MM, Pied S, Vigário AM 2010. Accumulation of Plasmodium berghei-infected red blood cells in the brain is crucial for the development of cerebral malaria in mice. Infect Immun 78: 4033-4039.

Barnwell JW, Asch AS, Nachman RL, Yamaya M, Aikawa M, Ingravallo P 1989. A human 88-kD membrane glycoprotein (CD36) functions in vitro as a receptor for a cytoadherence ligand on Plasmodium falciparum-infected erythrocytes. J Clin Invest 84: 765-772.

Basilico N, Parapini S, Sisto F, Omodeo-Salè F, Coghi P, Ravagnani F, Olliaro P, Taramelli D 2010. The lipid moiety of haemozoin (Malaria Pigment) and $P$. falciparum parasitised red blood cells bind synthetic and native endothelin-1. J Biomed Biotechnol 2010: 854927.

Beare NA, Harding SP, Taylor TE, Lewallen S, Molyneux ME 2009. Perfusion abnormalities in children with cerebral malaria and malarial retinopathy. J Infect Dis 199: 263-271.

Beare NA, Riva CE, Taylor TE, Molyneux ME, Kayira K, White VA, Lewallen S, Harding SP 2006. Changes in optic nerve head blood flow in children with cerebral malaria and acute papilloedema. J Neurol Neurosurg Psychiatry 77: 1288-1290.

Berendt AR, Simmons DL, Tansey J, Newbold CI, Marsh K 1989. Intercellular adhesion molecule-1 is an endothelial cell adhesion receptor for Plasmodium falciparum. Nature 341: 57-59.

Bertin GI, Lavstsen T, Guillonneau F, Doritchamou J, Wang CW, Jespersen JS, Ezimegnon S, Fievet N, Alao MJ, Lalya F, Massougbodji A, Ndam NT, Theander TG, Deloron P 2013. Expression of the domain cassette 8 Plasmodium falciparum erythrocyte membrane protein 1 is associated with cerebral malaria in Benin. PLOS ONE 8: e68368.

Boisramé-Helms J, Kremer H, Schini-Kerth V, Meziani F 2013. Endothelial dysfunction in sepsis. Curr Vasc Pharmacol 11: 150-160.

Boivin MJ 2002. Effects of early cerebral malaria on cognitive ability in Senegalese children. J Dev Behav Pediatr 23: e353.

Boivin MJ, Bangirana P, Byarugaba J, Opoka RO, Idro R, Jurek AM, 
John CC 2007. Cognitive impairment after cerebral malaria in children: a prospective study. Pediatrics 119: e360.

Brewster DR, Kwiatkowski D, White NJ 1990. Neurological sequelae of cerebral malaria in children. Lancet 336: 1039-1043.

Browatzki M, Pfeiffer CA, Schmidt J, Kranzhöfer R 2005. Endothelin-1 induces CD40 but not IL-6 in human monocytes via the proinflammatory transcription factor NF-kappaB. Eur J Med Res 10: 197-201.

Brown A, Turner L, Christoffersen S, Andrews KA, Szestak T, Zhao Y, Larsen S, Craig AG, Higgins MK 2013. Molecular architecture of a complex between an adhesion protein from the malaria parasite and intracellular adhesion molecule 1. J Biol Chem 288: 5992-6003.

Cabrales P, Carvalho LJ 2010. Intravital microscopy of the mouse brain microcirculation using a closed cranial window. $J$ Vis Exp 18: pii-2184.

Cabrales P, Martins YC, Ong PK, Zanini GM, Frangos JA, Carvalho LJ 2013. Cerebral tissue oxygenation impairment during experimental cerebral malaria. Virulence 4: 686-697.

Cabrales P, Zanini GM, Meays D, Frangos JA, Carvalho LJ 2010. Murine cerebral malaria is associated with a vasospasm-like microcirculatory dysfunction and survival upon rescue treatment is markedly increased by nimodipine. Am J Pathol 176: 1306-1315.

Cabrales P, Zanini GM, Meays D, Frangos JA, Carvalho LJ 2011. Nitric oxide protection against murine cerebral malaria is associated with improved cerebral microcirculatory physiology. J Infect Dis 203: 1454-1463.

Caló G, Gratton JP, Télémaque S, D’Orléans-Juste P, Regoli D 1996. Pharmacology of endothelins: vascular preparations for studying ETA and ETB receptors. Mol Cell Biochem 154: 31-37.

Carrol ED 2011. Angiopoietins as prognostic biomarkers and effector molecules in severe sepsis. Crit Care Med 39: 2203-2204.

Carter JA, Mung'ala-Odera V, Neville BG, Murira G, Mturi N, Musumba C, Newton CR 2005. Persistent neurocognitive impairments associated with severe falciparum malaria in Kenyan children. J Neurol Neurosurg Psychiatry 76: 476-481.

Carvalho LJ 2010. Murine cerebral malaria: how far from human cerebral malaria? Trends Parasitol 26: 271-272.

Clark IA, Rockett KA, Cowden WB 1991. Proposed link between cytokines, nitric oxide and human cerebral malaria. Parasitol Today 7: 205-207.

Clemmer L, Martins YC, Zanini GM, Frangos JA, Carvalho LJ 2011. Artemether and artesunate show the highest efficacies in rescuing mice with late-stage cerebral malaria and rapidly decrease leukocyte accumulation in the brain. Antimicrob Agents Chemother 55: 1383-1390.

Conroy AL, Glover SJ, Hawkes M, Erdman LK, Seydel KB, Taylor TE, Molyneux ME, Kain KC 2012. Angiopoietin-2 levels are associated with retinopathy and predict mortality in Malawian children with cerebral malaria: a retrospective case-control study. Crit Care Med 40: 952-959.

Conroy AL, Lafferty EI, Lovegrove FE, Krudsood S, Tangpukdee N, Liles WC, Kain KC 2009. Whole blood angiopoietin-1 and 2 levels discriminate cerebral and severe (non-cerebral) malaria from uncomplicated malaria. Malar J 8: 295.

Conroy AL, Phiri H, Hawkes M, Glover S, Mallewa M, Seydel KB, Taylor TE, Molyneux ME, Kain KC 2010. Endothelium-based biomarkers are associated with cerebral malaria in Malawian children: a retrospective case-control study. PLoS ONE 5: e15291.

Craig AG, Grau GE, Janse C, Kazura JW, Milner D, Barnwell JW, Turner G, Langhorne J 2012. The role of animal models for research on severe malaria. PLoS Pathog 8: e1002401.
Dai M, Freeman B, Bruno FP, Shikani HJ, Tanowitz HB, Weiss LM, Reznik SE, Stephani RA, Desruisseaux MS 2012. The novel ETA receptor antagonist HJP-272 prevents cerebral microvascular hemorrhage in cerebral malaria and synergistically improves survival in combination with an artemisinin derivative. Life Sci 91: 687-692.

David S, Kümpers P, van Slyke P, Parikh SM 2013. Mending leaky blood vessels: the angiopoietin-Tie2 pathway in sepsis. J Pharmacol Exp Ther 345: 2-6.

Davis S, Aldrich TH, Jones PF, Acheson A, Compton DL, Jain V, Ryan TE, Bruno J, Radziejewski C, Maisonpierre PC, Yancopoulos GD 1996. Isolation of angiopoietin-1, a ligand for the TIE2 receptor, by secretion-trap expression cloning. Cell 87: 1161-1169.

de Souza JB, Hafalla JC, Riley EM, Couper KN 2010. Cerebral malaria: why experimental murine models are required to understand the pathogenesis of disease. Parasitology 137: 755-772.

de Souza JB, Riley EM 2002. Cerebral malaria: the contribution of studies in animal models to our understanding of immunopathogenesis. Microbes Infect 4: 291-300.

Diaz-Sanchez A, Matilla A, Nuñez O, Lorente R, Fernandez A, Rincón D, Campos R, Bañares R, Clemente G 2013. Serum angiopoietin-2 level as a predictor of tumor invasiveness in patients with hepatocellular carcinoma. Scand J Gastroenterol 48: 334-343.

Dietmann A, Lackner P, Helbok R, Spora K, Issifou S, Lell B, Reindl M, Kremsner PG, Schmutzhard E 2008. Opposed circulating plasma levels of endothelin-1 and C-type natriuretic peptide in children with Plasmodium falciparum malaria. Malar J 7: 253.

Dondorp A, Nosten F, Stepniewska K, Day N, White N, South East Asian Quinine Artesunate Malaria Trial (SEAQUAMAT) Group 2005. Artesunate versus quinine for treatment of severe falciparum malaria: a randomised trial. Lancet 366: 717-725.

Dondorp AM, Fanello CI, Hendriksen IC, Gomes E, Seni A, Chhaganlal KD, Bojang K, Olaosebikan R, Anunobi N, Maitland K, Kivaya E, Agbenyega T, Nguah SB, Evans J, Gesase S, Kahabuka C, Mtove G, Nadjm B, Deen J, Mwanga-Amumpaire J, Nansumba M, Karema C, Umulisa N, Uwimana A, Mokuolu OA, Adedoyin OT, Johnson WB, Tshefu AK, Onyamboko MA, Sakulthaew T, Ngum WP, Silamut K, Stepniewska K, Woodrow CJ, Bethell D, Wills B, Oneko M, Peto TE, von Seidlein L, Day NP, White NJ, for the AQUAMAT Group 2010. Artesunate versus quinine in the treatment of severe falciparum malaria in African children (AQUAMAT): an open-label, randomised trial. Lancet 376: 1647-1657.

Dondorp AM, Planche T, de Bel EE, Angus BJ, Chotivanich KT, Silamut K, Romijn JA, Ruangveerayuth R, Hoek FJ, Kager PA, Vreeken J, White NJ 1998. Nitric oxides in plasma, urine andcerebrospinal fluid in patients with severe falciparum malaria. $\mathrm{Am}$ J Trop Med Hyg 59: 497-502.

Edvinsson L 2009. Cerebrovascular endothelin receptor upregulation in cerebral ischemia. Curr Vasc Pharmacol 7: 26-33.

Ehrenreich H, Kehrl JH, Anderson RW, Rieckmann P, Vitkovic L, Coligan JE, Fauci AS 1991. A vasoactive peptide, endothelin-3, is produced by and specifically binds to primary astrocytes. Brain Res 538: 54-58.

Erdman LK, Dhabangi A, Musoke C, Conroy AL, Hawkes M, Higgins S, Rajwans N, Wolofsky KT, Streiner DL, Liles WC, CsertiGazdewich CM, Kain KC 2011. Combinations of host biomarkers predict mortality among Ugandan children with severe malaria: a retrospective case-control study. PLOS ONE 6: e17440.

Evans NJ, Walker JW 2008. Endothelin receptor dimers evaluated by FRET, ligand binding and calcium mobilization. Biophys $J$ 95: 483-492.

Fagiani E, Christofori G 2013. Angiopoietins in angiogenesis. Cancer Lett 328: 18-26. 
Favre N, Ryffel B, Rudin W 1999. The development of murine cerebral malaria does not require nitric oxide production. Parasitology 118: 135-138.

Fiedler U, Augustin HG 2006. Angiopoietins: a link between angiogenesis and inflammation. Trends Immunol 27: 552-558.

Fiedler U, Reiss Y, Scharpfenecker M, Grunow V, Koidl S, Thurston G, Gale NW, Witzenrath M, Rosseau S, Suttorp N, Sobke A, Herrmann M, Preissner KT, Vajkoczy P, Augustin HG 2006. Angiopoietin-2 sensitizes endothelial cells to TNF-alpha and has a crucial role in the induction of inflammation. Nat Med 12: 235-239.

Fiedler U, Scharpfenecker M, Koidl S, Hegen A, Grunow V, Schmidt JM, Kriz W, Thurston G, Augustin HG 2004. The Tie-2 ligand angiopoietin-2 is stored in and rapidly released upon stimulation from endothelial cell Weibel-Palade bodies. Blood 103: 4150-4156.

Filipovich T, Fleisher-Berkovich S 2008. Regulation of glial inflammatory mediators synthesis: possible role of endothelins. Peptides 29: 2250-2256.

Finney CA, Hawkes CA, Kain DC, Dhabangi A, Musoke C, CsertiGazdewich C, Oravecz T, Liles WC, Kain KC 2011. S1P is associated with protection in human and experimental cerebral malaria. Mol Med 17: 717-725.

Forstermann U, Sessa WC 2012. Nitric oxide synthases: regulation and function. Eur Heart $J$ 33: 829-837.

Franke-Fayard B, Fonager J, Braks A, Khan SM, Janse CJ 2010. Sequestration and tissue accumulation of human malaria parasites: can we learn anything from rodent models of malaria? PLoS Pathog 6: e1001032.

Gay F, Zougbédé S, N'dilimabaka N, Rebollo A, Mazier D, Moreno A 2012. Cerebral malaria: what is known and what is on research. Rev Neurol 168: 239-256

Gómez-Garre D, Guerra M, González E, López-Farré A, Riesco A, Caramelo C, Escanero J, Egido J 1992. Aggregation of human polymorphonuclear leukocytes by endothelin: role of plateletactivating factor. Eur J Pharmacol 224: 167-172.

Gramaglia I, Sobolewski P, Meays D, Contreras R, Nolan JP, Frangos JA, Intaglietta M, van der Heyde HC 2006. Low nitric oxide bioavailability contributes to the genesis of experimental cerebral malaria. Nat Med 12: 1417-1422.

Grau GE, Craig AG 2012. Cerebral malaria pathogenesis: revisiting parasite and host contributions. Future Microbiol 7: 291-302.

Guo J, Shi Z, Yang K, Tian JH, Jiang L 2012. Endothelin receptor antagonists for sub arachnoid hemorrhage. Cochrane Database Syst Rev 9: CD008354.

Hammes HP, Lin J, Wagner P, Feng Y, Vom Hagen F, Krzizok T, Renner O, Breier G, Brownlee M, Deutsch U 2004. Angiopoietin-2 causes pericyte dropout in the normal retina: evidence for involvement in diabetic retinopathy. Diabetes 53: 1104-1110.

Hawkes M, Opoka RO, Namasopo S, Miller C, Thorpe KE, Lavery JV, Conroy AL, Liles WC, John CC, Kain KC 2011. Inhaled nitric oxide for the adjunctive therapy of severe malaria: protocol for a randomized controlled trial. Trials 12: 176.

Hemsén A, Larsson O, Lundberg JM 1991. Characteristics of endothelin A and B binding sites and their vascular effects in pig peripheral tissues. Eur J Pharmacol 208: 313-322.

Hunt NH, Grau GE, Engwerda C, Barnum SR, van der Heyde H, Hansen DS, Schofield L, Golenser J 2010. Murine cerebral malaria: the whole story. Trends Parasitol 26: 272-274.

Idro R, Jenkins NE, Newton CR 2005. Pathogenesis, clinical features and neurological outcome of cerebral malaria. Lancet Neurol 4: 827-840.
Ignarro LJ, Buga GM, Wood KS, Byrns RE, Chaudhuri G 1987. Endothelium-derived relaxing factor produced and released from artery and vein is nitric oxide. Proc Natl Acad Sci USA 84: 9265-9269.

Jain V, Lucchi NW, Wilson NO, Blackstock AJ, Nagpal AC, Joel PK, Singh MP, Udhayakumar V, Stiles JK, Singh N 2011. Plasma levels of angiopoietin-1 and 2 predict cerebral malaria outcome in Central India. Malar J 10: 383.

John CC, Bangirana P, Byarugaba J, Opoka RO, Idro R, Jurek AM, Wu B, Boivin MJ 2008. Cerebral malaria in children is associated with long-term cognitive impairment. Pediatrics 122: e92-e99.

Jones N, Chen SH, Sturk C, Master Z, Tran J, Kerbel RS, Dumont DJ 2003. A unique autophosphorylation site on Tie2/Tek mediates Dok-R phosphotyrosine binding domain binding and function. Mol Cell Biol 23: 2658-2668.

Jones N, Master Z, Jones J, Bouchard D, Gunji Y, Sasaki H, Daly R, Alitalo K, Dumont DJ 1999. Identification of Tek/Tie2 binding partners. Binding to a multifunctional docking site mediates cell survival and migration. $J$ Biol Chem 274: 30896-30905.

Kampfl A, Pfausler B, Haring HP, Denchev D, Donnemiller E, Schmutzhard E 1997. Impaired microcirculation and tissue oxygenation in human cerebral malaria: a single photon emission computed tomography and near-infrared spectroscopy study. Am J Trop Med Hyg 56: 585-587.

Kampondeni SD, Potchen MJ, Beare NA, Seydel KB, Glover SJ, Taylor TE, Birbeck GL 2013. MRI findings in a cohort of brain injured survivors of pediatric cerebral malaria. Am J Trop Med Hyg 88: 542-546.

Kedzierski RM, Yanagisawa M 2001. Endothelin system: the doubleedged sword in health and disease. Annu Rev Pharmacol Toxicol 41: 851-876.

Kennan RP, Machado FS, Lee SC, Desruisseaux MS, Wittner M, Tsuji M, Tanowitz HB 2005. Reduced cerebral blood flow and Nacetyl aspartate in a murine model of cerebral malaria. Parasitol Res 96: 302-307.

Keyrouz SG, Diringer MN 2007. Clinical review: prevention and therapy of vasospasm in subarachnoid hemorrhage. Crit Care 11: 220.

Kim H, Erdman LK, Lu Z, Serghides L, Zhong K, Dhabangi A, Musoke C, Gerard C, Cserti-Gazdewich C, Liles WC, Kain KC 2014. Functional roles for C5a and C5aR but not C5L2 in the pathogenesis of human and experimental cerebral malaria. Infect Immun 82: 371-379.

Kim I, Moon SO, Park SK, Chae SW, Koh GY 2001. Angiopoietin-1 reduces VEGF-stimulated leukocyte adhesion to endothelial cells by reducing ICAM-1, VCAM-1 and E-selectin expression. Circ Res 89: 477-479.

Kohan DE, Cleland JG, Rubin LJ, Theodorescu D, Barton M 2012. Clinical trials with endothelin receptor antagonists: what went wrong and where can we improve? Life Sci 91: 528-539.

Kraemer SM, Smith JD 2006. A family affair: var genes, PfEMP1 binding and malaria disease. Curr Opin Microbiol 9: 374-380.

Kremsner PG, Nüssler A, Neifer S, Chaves MF, Bienzle U, Senaldi G, Grau GE 1993. Malaria antigen and cytokine-induced production of reactive nitrogen intermediates by murine macrophages: no relevance to the development of experimental cerebral malaria. Immunology 78: 286-290.

Langhorne J, Buffet P, Galinski M, Good M, Harty J, Leroy D, Mota MM, Pasini E, Rénia L, Riley E, Stins M, Duffy P 2011. The relevance of non-human primate and rodent malaria models for humans. Malar J 10: 23.

Lavstsen T, Turner L, Saguti F, Magistrado P, Rask TS, Jespersen JS, Wang CW, Berger SS, Baraka V, Marquard AM, Seguin-Orlan- 
do A, Willerslev E, Gilbert MT, Lusingu J, Theander TG 2012. Plasmodium falciparum erythrocyte membrane protein 1 domain cassettes 8 and 13 are associated with severe malaria in children. Proc Natl Acad Sci USA 109: e1791-800.

Lee HJ, Cho CH, Hwang SJ, Choi HH, Kim KT, Ahn SY, Kim JH, Oh JL, Lee GM, Koh GY 2004. Biological characterization of angiopoietin-3 and angiopoietin-4. FASEB J 18: 1200-1208.

Lewallen S, Taylor TE, Molyneux ME, Wills BA, Courtright P 1993. Ocular fundus findings in Malawian children with cerebral malaria. Ophthalmology 100: 857-861.

Li JJ, Wu LH, Cao Q, Yuan Y, Yang L, Guo ZY, Kaur C, Sivakumar V, Ling EA, Wu CY 2010. Endothelins-1/3 and endothelin-A/B receptors expressing glial cells with special reference to activated microglia in experimentally induced cerebral ischemia in the adult rats. Neuroscience 167: 665-677.

Liu C, Zhao W, Christ GJ, Gladwin MT, Kim-Shapiro DB 2013. Nitric oxide scavenging by red cell microparticles. Free Radic Biol Med 65: $1164-1173$.

Looareesuwan S, Laothamatas J, Brown TR, Brittenham GM 2009. Cerebral malaria: a new way forward with magnetic resonance imaging (MRI). Am J Trop Med Hyg 81: 545-547.

Looareesuwan S, Wilairatana P, Krishna S, Kendall B, Vannaphan S, Viravan C, White NJ 1995. Magnetic resonance imaging of the brain in patients with cerebral malaria. Clin Infect Dis 21: 300-309.

Lopansri BK, Anstey NM, Weinberg JB, Stoddard GJ, Hobbs MR, Levesque MC, Mwaikambo ED, Granger DL 2003. Low plasma arginine concentrations in children with cerebral malaria and decreased nitric oxide production. Lancet 361: 676-678.

Lovegrove FE, Gharib SA, Patel SN, Hawkes CA, Kain KC, Liles WC 2007. Expression microarray analysis implicates apoptosis and interferon-responsive mechanisms in susceptibility to experimental cerebral malaria. Am J Pathol 171: 1894-1903.

Lovegrove FE, Tangpukdee N, Opoka RO, Lafferty EI, Rajwans N, Hawkes M, Krudsood S, Looareesuwan S, John CC, Liles WC, Kain KC 2009. Serum angiopoietin-1 and 2 levels discriminate cerebral malaria from uncomplicated malaria and predict clinical outcome in African children. PLoS ONE 4: e4912.

Lucchi NW, Jain V, Wilson NO, Singh N, Udhayakumar V, Stiles JK 2011. Potential serological biomarkers of cerebral malaria. Dis Markers 31: 327-335.

Machado FS, Desruisseaux MS, Nagajyothi, Kennan RP, Hetherington HP, Wittner M, Weiss LM, Lee SC, Scherer PE, Tsuji M, Tanowitz HB 2006. Endothelin in a murine model of cerebral malaria. Exp Biol Med 231: 1176-1181.

MacMullin G, Mackenzie R, Lau R, Khang J, Zhang H, Rajwans N, Liles WC, Pillai DR 2012. Host immune response in returning travellers infected with malaria. Malar J 11: 148

Maisonpierre PC, Suri C, Jones PF, Bartunkova S, Wiegand SJ, Radziejewski C, Compton D, McClain J, Aldrich TH, Papadopoulos N, Daly TJ, Davis S, Sato TN, Yancopoulos GD 1997. Angiopoietin-2, a natural antagonist for Tie2 that disrupts in vivo angiogenesis. Science 277: 55-60.

Marsh K, English M, Crawley J, Peshu N 1996. The pathogenesis of severe malaria in African children. Ann Trop Med Parasitol 90: 395-402.

Martins YC, Clemmer L, Orjuela-Sánchez P, Zanini GM, Ong PK, Frangos JA, Carvalho LJ 2013. Slow and continuous delivery of a low dose of nimodipine improves survival and electrocardiogram parameters in rescue therapy of mice with experimental cerebral malaria. Malar J 12: 138
Martins YC, Smith MJ, Pelajo-Machado M, Werneck GL, Lenzi HL, Daniel-Ribeiro CT, Carvalho LJ 2009. Characterization of cerebral malaria in the outbred Swiss Webster mouse infected by Plasmodium berghei ANKA. Int J Exp Pathol 90: 119-130.

Martins YC, Zanini GM, Frangos JA, Carvalho LJM 2012. Efficacy of different nitric oxide-based strategies in preventing experimental cerebral malaria by Plasmodium berghei ANKA. PLoS ONE 7: e32048.

Masaki T 2004. Historical review: endothelin. Trends Pharmacol Sci 25: 219-224.

Matsuo Y, Mihara S, Ninomiya M, Fujimoto M 2001. Protective effect of endothelin type A receptor antagonist on brain edema and injury after transient middle cerebral artery occlusion in rats. Stroke 32: 2143-2148.

McCarron RM, Wang L, Stanimirovic DB, Spatz M 1993. Endothelin induction of adhesion molecule expression on human brain microvascular endothelial cells. Neurosci Lett 156: 31-34.

Milner CS, Hansen TM, Singh H, Brindle NP 2009. Roles of the receptor tyrosine kinases Tie1 and Tie2 in mediating the effects of angiopoietin-1 on endothelial permeability and apoptosis. Microvasc Res 77: 187-191.

Mohanty S, Mishra SK, Pati SS, Pattnaik J, Das BS 2003. Complications and mortality patterns due to Plasmodium falciparum malaria in hospitalized adults and children, Rourkela, Orissa, India. Trans R Soc Trop Med Hyg 97: 69-70.

Morris CR, Gladwin MT, Kato GJ 2008. Nitric oxide and arginine dysregulation: a novel pathway to pulmonary hypertension in hemolytic disorders. Curr Mol Med 8: 620-632.

Moxon CA, Chisala NV, Wassmer SC, Taylor TE, Seydel KB, Molyneux ME, Faragher B, Kennedy N, Toh CH, Craig AG, Heyderman RS 2014. Persistent endothelial activation and inflammation after Plasmodium falciparum infection in Malawian children. J Infect Dis 209: 610-615.

Moxon CA, Wassmer SC, Milner Jr DA, Chisala NV, Taylor TE, Seydel $\mathrm{KB}$, Molyneux ME, Faragher B, Esmon CT, Downey C, Toh CH, Craig AG, Heyderman RS 2013. Loss of endothelial protein C receptors links coagulation and inflammation to parasite sequestration in cerebral malaria in African children. Blood 122: 842-851.

Murphy SC, Breman JG 2001. Gaps in the childhood malaria burden in Africa: cerebral malaria, neurological sequelae, anemia, respiratory distress, hypoglycemia and complications of pregnancy. Am J Trop Med Hyg 64: 57-67.

Murray CJ, Rosenfeld LC, Lim SS, Andrews KG, Foreman KJ, Haring D, Fullman N, Naghavi M, Lozano R, Lopez AD 2012. Global malaria mortality between 1980 and 2010: a systematic analysis. Lancet 379: 413-431.

Omodeo-Salè F, Cortelezzi L, Vommaro Z, Scaccabarozzi D, Dondorp AM 2010. Dysregulation of L-arginine metabolism and bioavailability associated to free plasma heme. Am J Physiol Cell Physiol 299: 148-154.

Ong PK, Meays D, Frangos JA, Carvalho LJ 2013a. A chronic scheme of cranial window preparation to study pial vascular reactivity in murine cerebral malaria. Microcirculation 20: 394-404.

Ong PK, Melchior B, Martins YC, Hofer A, Orjuela-Sánchez P, Cabrales P, Zanini GM, Frangos JA, Carvalho LJ 2013b. Nitric oxide synthase dysfunction contributes to impaired cerebroarteriolar reactivity in experimental cerebral malaria. PLoS Pathog 9: e1003444.

Orjuela-Sánchez P, Ong PK, Zanini GM, Melchior B, Martins YC, Meays D, Frangos JA, Carvalho LJ 2013. Transdermal glyceryl trinitrate as an effective adjunctive treatment with artemether for late-stage experimental cerebral malaria. Antimicrob Agents Chemother 57: 5462-5471. 
Polder TW, Jerusalem CR, Eling WM 1991. Morphological characteristics of intracerebral arterioles in clinical (Plasmodium falciparum) and experimental (Plasmodium berghei) cerebral malaria. J Neurol Sci 101: 35-46.

Pongponratn E, Riganti M, Punpoowong B, Aikawa M 1991. Microvascular sequestration of parasitized erythrocytes in human falciparum malaria: a pathological study. Am J Trop Med Hyg 44: 168-175.

Pongponratn E, Turner GD, Day NP, Phu NH, Simpson JA, Stepniewska K, Mai NT, Viriyavejakul P, Looareesuwan S, Hien TT, Ferguson DJ, White NJ 2003. An ultrastructural study of the brain in fatal Plasmodium falciparum malaria. Am J Trop Med Hyg 69: 345-359.

Ponsford MJ, Medana IM, Prapansilp P, Hien TT, Lee SJ, Dondorp AM, Esiri MM, Day NP, White NJ, Turner GD 2012. Sequestration and microvascular congestion are associated with coma in human cerebral malaria. J Infect Dis 205: 663-671.

Potchen MJ, Kampondeni SD, Seydel KB, Birbeck GL, Hammond CA, Bradley WG, DeMarco JK, Glover SJ, Ugorji JO, Latourette MT, Siebert JE, Molyneux ME, Taylor TE 2012. Acute brain MRI findings in 120 Malawian children with cerebral malaria: new insights into an ancient disease. AJNR Am J Neuroradiol 33: $1740-1746$.

Prapansilp P, Medana I, Mai NT, Day NP, Phu NH, Yeo TW, Hien TT, White NJ, Anstey NM, Turner GD 2013. A clinicopathological correlation of the expression of the angiopoietin-Tie-2 receptor pathway in the brain of adults with Plasmodium falciparum malaria. Malar J 12: 50 .

Ramzy D, Rao V, Tumiati LC, Xu N, Sheshgiri R, Miriuka S, Delgado DH, Ross HJ 2006. Elevated endothelin-1 levels impair nitric oxide homeostasis through a PKC-dependent pathway. Circulation 114: I319-I326.

Reeder JC, Cowman AF, Davern KM, Beeson JG, Thompson JK, Rogerson SJ, Brown GV 1999. The adhesion of Plasmodium falciparum-infected erythrocytes to chondroitin sulfate A is mediated by P. falciparum erythrocyte membrane protein 1. Proc Natl Acad Sci USA 96: 5198-5202.

Reijerkerk A, Lakeman KA, Drexhage JA, van het Hof B, van Wijck Y, van der Pol SM, Kooij G, Geerts D, de Vries HE 2012. Brain endothelial barrier passage by monocytes is controlled by the endothelin system. $J$ Neurochem 121: 730-737.

Rénia L, Grüner AC, Snounou G 2010. Cerebral malaria: in praise of epistemes. Trends Parasitol 26: 275-277.

Rénia L, Howland SW, Claser C, Charlotte GA, Suwanarusk R, Hui TT, Russell B, Ng LF 2012. Cerebral malaria: mysteries at the blood-brain barrier. Virulence 3: 193-201.

Riley EM, Couper KN, Helmby H, Hafalla JC, de Souza JB, Langhorne J, Jarra WB, Zavala F 2010. Neuropathogenesis of human and murine malaria. Trends Parasitol 26: 277-278

Roberts DD, Sherwood JA, Spitalnik SL, Panton LJ, Howard RJ, Dixit VM, Frazier WA, Miller LH, Ginsburg V 1985. Thrombospondin binds falciparum malaria parasitized erythrocytes and may mediate cytoadherence. Nature 318: 64-66.

Rother RP, Bell L, Hillmen P, Gladwin MT 2005. The clinical sequelae of intravascular hemolysis and extracellular plasma hemoglobin: a novel mechanism of human disease. JAMA 293: 1653-1662.

Rubanyi GM, Polokoff MA 1994. Endothelins: molecular biology, biochemistry, pharmacology, physiology and pathophysiology. Pharmacol Rev 46: 325-415.

Saharinen P, Eklund L, Miettinen J, Wirkkala R, Anisimov A, Winderlich M, Nottebaum A, Vestweber D, Deutsch U, Koh GY, Olsen BR, Alitalo K 2008. Angiopoietins assemble distinct Tie2 signalling complexes in endothelial cell-cell and cell-matrix contacts. Nat Cell Biol 10: 527-537.
Saida K, Kometani N, Uchide T, Mitsui Y 2002. Sequence analysis and expression of the mouse full-length vasoactive intestinal contractor/endothelin-2 gene (EDN2): comparison with the endothelin-1 gene (EDN1). Clin Sci (Lond) 103 (Suppl. 48): S84-S89.

Sakurai T, Yanagisawa M, Takuwa Y, Miyazaki H, Kimura S, Goto K, Masaki T 1990. Cloning of a cDNA encoding a non-isopeptideselective subtype of the endothelin receptor. Nature 348: 732-735.

Scherf A, Lopez-Rubio JJ, Riviere L 2008. Antigenic variation in Plasmodium falciparum. Annu Rev Microbiol 62: 445-470.

Serghides L, Kim H, Lu Z, Kain DC, Miller C, Francis RC, Liles WC, Zapol WM, Kain KC 2011. Inhaled nitric oxide reduces endothelial activation and parasite accumulation in the brain and enhances survival in experimental cerebral malaria. PLOS ONE 6: e27714.

Serghides L, McDonald CR, Lu Z, Friedel M, Cui C, Ho KT, Mount HT, Sled JG, Kain KC 2014. PPAR $\gamma$ agonists improve survival and neurocognitive outcomes in experimental cerebral malaria and induce neuroprotective pathways in human malaria. PLoS Pathog 10: e1003980.

Serirom S, Raharjo WH, Chotivanich K, Loareesuwan S, Kubes P, Ho M 2003. Anti-adhesive effect of nitric oxide on Plasmodium falciparum cytoadherence under flow. Am J Pathol 152: 1651-1660.

Silamut K, Phu NH, Whitty C, Turner GD, Louwrier K, Mai NT, Simpson JA, Hien TT, White NJ 1999. A quantitative analysis of the microvascular sequestration of malaria parasites in the human brain. Am J Pathol 155: 395-410.

Silver KL, Zhong K, Leke RG, Taylor DW, Kain KC 2010. Dysregulation of angiopoietins is associated with placental malaria and low birth weight. PLoS ONE 5: e9481.

Simonson MS 1993. Endothelins: multifunctional renal peptides. Physiol Rev 73: 375-411.

Solomon W, Wilson NO, Anderson L, Pitts S, Patrickson J, Liu M, Ford BD, Stiles JK 2014. Neuregulin-1 attenuates mortality associated with experimental cerebral malaria. J Neuroinflammation 11: 9.

Stevenson MM, Gros P, Olivier M, Fortin A, Serghides L 2010. Cerebral malaria: human versus mouse studies. Trends Parasitol 26: 274-275.

Trampuz A, Jereb M, Muzlovic I, Prabhu RM 2003. Clinical review: severe malaria. Crit Care 7: 315-323.

Tsukahara H, Ende H, Magazine HI, Bahou WF, Goligorsky MS 1994. Molecular and functional characterization of the non-isopeptideselective ETB receptor in endothelial cells. Receptor coupling to nitric oxide synthase. J Biol Chem 269: 21778-21785.

Turner GD, Morrison H, Jones M, Davis TM, Looareesuwan S, Buley ID, Gatter KC, Newbold CI, Pukritayakamee S, Nagachinta B, White NJ, Berendt AR 1994. An immunohistochemical study of the pathology of fatal malaria. Evidence for widespread endothelial activation and a potential role for intercellular adhesion molecule-1 in cerebral sequestration. Am J Pathol 145: 1057-1069.

Turner L, Lavstsen T, Berger SS, Wang CW, Petersen JE, Avril M, Brazier AJ, Freeth J, Jespersen JS, Nielsen MA, Magistrado P, Lusingu J, Smith JD, Higgins MK, Theander TG 2013. Severe malaria is associated with parasite binding to endothelial protein C receptor. Nature 498: 502-505.

van der Heyde HC, Nolan J, Combes V, Gramaglia I, Grau GE 2006. A unified hypothesis for the genesis of cerebral malaria: sequestration, inflammation and hemostasis leading to microcirculatory dysfunction. Trends Parasitol 22: 503-508.

Vignon-Zellweger N, Heiden S, Miyauchi T, Emoto N 2012. Endothelin and endothelin receptors in the renal and cardiovascular systems. Life Sci 91: 490-500. 
Wagner OF, Christ G, Wojta J, Vierhapper H, Parzer S, Nowotny PJ, Schneider B, Waldhäusl W, Binder BR 1992. Polar secretion of endothelin-1 by cultured endothelial cells. J Biol Chem 267: e16066-8.

Weinberg JB, Yeo TW, Mukemba JP, Florence SM, Volkheimer AD, Wang H, Chen Y, Rubach M, Granger DL, Mwaikambo ED, Anstey NM 2014. Dimethylarginines: endogenous inhibitors of nitric oxide synthesis in children with falciparum malaria. $J$ Infect Dis PMID: 24620026.

Wenisch C, Wenisch H, Wilairatana P, Looareesuwan S, Vannaphan S, Wagner O, Graninger W, Schonthal E, Rumpold H 1996. Big endothelin in patients with complicated Plasmodium falciparum malaria. J Infect Dis 173: 1281-1284.

White NJ, Turner GD, Day NP, Dondorp AM 2013. Lethal malaria: Marchiafava and Bignami were right. J Infect Dis 208: 192-198.

White NJ, Turner GD, Medana IM, Dondorp AM, Day NP 2010. The murine cerebral malaria phenomenon. Trends Parasitol 26: 11-15.

White VA, Lewallen S, Beare N, Kayira K, Carr RA, Taylor TE 2001. Correlation of retinal haemorrhages with brain haemorrhages in children dying of cerebral malaria in Malawi. Trans $R$ Soc Trop Med Hyg 95: 618-621.

WHO/CDC - World Health Organization/Communicable Diseases Cluster 2000. Severe falciparum malaria. Trans $R$ Soc Trop Med Hyg 94 (Suppl. 1): S1-S90.

Xu Y, Yu Q 2001. Angiopoietin-1, unlike angiopoietin-2, is incorporated into the extracellular matrix via its linker peptide region. J Biol Chem 276: 34990-34998.

Yeo TW, Lampah DA, Gitawati R, Tjitra E, Kenangalem E, Granger DL, Weinberg JB, Lopansri BK, Price RN, Celermajer DS, Duffull SB, Anstey NM 2008a. Safety profile of L-arginine infusion in moderately severe falciparum malaria. PLoS ONE 3: e2347.

Yeo TW, Lampah DA, Gitawati R, Tjitra E, Kenangalem E, McNeil YR, Darcy CJ, Granger DL, Weinberg JB, Lopansri BK, Price RN, Duffull SB, Celermajer DS, Anstey NM 2007. Impaired nitric oxide bioavailability and L-arginine reversible endothelial dysfunction in adults with falciparum malaria. J Exp Med 204: 2693-2704.

Yeo TW, Lampah DA, Gitawati R, Tjitra E, Kenangalem E, McNeil YR, Darcy CJ, Granger DL, Weinberg JB, Lopansri BK, Price RN, Duffull SB, Celermajer DS, Anstey NM 2008b. Recovery of endothelial function in severe falciparum malaria: relationship with improvement in plasma L-arginine and blood lactate concentrations. J Infect Dis 198: 602-608.

Yeo TW, Lampah DA, Gitawati R, Tjitra E, Kenangalem E, Piera K, Price RN, Duffull SB, Celermajer DS, Anstey NM 2008c. Angiopoietin-2 is associated with decreased endothelial nitric oxide and poor clinical outcome in severe falciparum malaria. Proc Natl Acad Sci USA 105: 17097-17102.

Yeo TW, Lampah DA, Rooslamiati I, Gitawati R, Tjitra E, Kenangalem E, Price RN, Duffull SB, Anstey NM 2013. A randomized pilot study of L-arginine infusion in severe falciparum malaria: preliminary safety, efficacy and pharmacokinetics. PLoS ONE 8: e69587.

Yeo TW, Lampah DA, Tjitra E, Gitawati R, Darcy CJ, Jones C, Kenangalem E, McNeil YR, Granger DL, Lopansri BK, Weinberg JB, Price RN, Duffull SB, Celermajer DS, Anstey NM 2010a. Increased asymmetric dimethylarginine in severe falciparum malaria: association with impaired nitric oxide bioavailability and fatal outcome. PLoS Pathog 6: e1000868.

Yeo TW, Lampah DA, Tjitra E, Gitawati R, Kenangalem E, Piera K, Granger DL, Lopansri BK, Weinberg JB, Price RN, Duffull SB, Celermajer DS, Anstey NM 2009. Relationship of cell-free hemoglobin to impaired endothelial nitric oxide bioavailability and perfusion in severe falciparum malaria. J Infect Dis 200: 1522-1529.

Yeo TW, Lampah DA, Tjitra E, Piera K, Gitawati R, Kenangalem E, Price RN, Anstey NM 2010b. Greater endothelial activation, Weibel-Palade body release and host inflammatory response to Plasmodium vivax compared with Plasmodium falciparum: a prospective study in Papua, Indonesia. J Infect Dis 202: 109-112.

Yeo TW, Rooslamiati I, Gitawati R, Tjitra E, Lampah DA, Kenangalem E, McNeil YR, Price RN, Anstey NM, Duffull SB 2008d. Pharmacokinetics of L-arginine in adults with moderately severe malaria. Antimicrob Agents Chemother 52: 4381-4387.

Yuan HT, Khankin EV, Karumanchi SA, Parikh SM 2009. Angiopoietin 2 is a partial agonist/antagonist of Tie2 signaling in the endothelium. Mol Cell Biol 29: 2011-2022.

Zanini GM, Cabrales P, Barkho W, Frangos JA, Carvalho LJM 2011. Exogenous nitric oxide decreases brain vascular inflammation, leakage and venular resistance during Plasmodium berghei ANKA infection in mice. J Neuroinflammation 8: 66.

Zanini GM, Martins YC, Cabrales P, Frangos JA, Carvalho LJ 2012. S-nitrosoglutathione prevents experimental cerebral malaria. J Neuroimmune Pharmacol 7: 477-487. 